\title{
Recycling Plastics: Middle School Students Create Solutions During a Summer Camp
}

\author{
Ergun Akleman ${ }^{1}$, Luciana Barroso 2,3 , Mary M. Capraro 2,4* , Terry Creasy ${ }^{1}$, Kenneth Fleming 4 , \\ Weiling $\mathrm{He}^{1}$, Hong Liang ${ }^{3}$, Ashley M. Williams ${ }^{2,4}$
}

\author{
${ }^{1}$ Texas A\&M University, College of Architecture, College Station, USA \\ ${ }^{2}$ Texas A\&M University, Aggie STEM, USA \\ ${ }^{3}$ Texas A\&M University, College of Engineering, USA \\ ${ }^{4}$ Texas A\&M University, College of Education and Human Development, USA
}

*Corresponding Author: mmcapraro@tamu.edu

Citation: Akleman, E., Barroso, L., Capraro, M. M., Creasy, T., Fleming, K., He, W., Liang, H. and Williams, A. M. (2019). Recycling Plastics: Middle School Students Create Solutions During a Summer Camp. European Journal of STEM Education, 4(1), 10. https://doi.org/10.20897/ ejsteme/ 6341

Published: December 5, 2019

\begin{abstract}
Four distinct plastics recycling projects created by middle school students emerged from a one-week long plastics recycling activity incorporated within a science, technology, engineering, and mathematics (STEM) residential summer camp at a research-intensive university. The plastics recycling activity was a projectbased learning (PBL) activity facilitated by STEM experts in geometry, architecture, and materials science. Specific instruction involving mathematics and science concepts was provided to emphasize contentspecific knowledge related to plastics recycling. A rubric was applied and used to determine evidence of learning manifested in participants' final presentations. Participants' final presentations demonstrated mixed results in terms of student learning outcomes, but indicated that campers demonstrated a clear sense of social environmental awareness and responsibility toward recycling plastics.
\end{abstract}

Keywords: recycling, STEM PBL, middle school (ages 11-14), informal learning, social environmental awareness

\section{INTRODUCTION}

Throughout history, mankind has strived to identify innovative solutions to problems for the betterment of society. Today, the need for innovative problem solvers remains just as imperative, particularly in relation to environmental issues and recycling. Educating the next generation of problem solvers requires a critical evaluation of the learning opportunities that students have in formal and informal settings. Doing so will ensure that current and future generations are properly equipped to make informed and inspired decisions when addressing existing environmental problems, such as the growing need for effective recycling programs. Therefore, the purpose of the study was to determine if middle school students, when presented with an environmental problem and contentspecific knowledge about materials science, architecture, 3-D printing, and geometry and topology, would be able to integrate this knowledge into a socially responsible solution of their own design that could address the ubiquitous problem of plastic bottle waste. In particular, we examined how rich and in-depth content knowledge in these fields combined with the true integration of science, technology, engineering, and mathematics (STEM) disciplines facilitated middle school campers' development of environmental awareness and social responsibility (Watts, 2001) during a one-week camp while working on a recycling plastics project. In the present study, we analyzed social 
environmental awareness and responsibility as a single conceptual unit that refers to a mindfulness about factors that affect the world and an increasing awareness of how to correct identified environmental problems.

There have been a number examples of landmark innovations in which both the search for and identification of solutions have exercised, bridged, and expanded STEM discipline-related knowledge (Chandra and Dong, 2015). Pressing real-world challenges drove many of these integrated STEM advancements. For instance, the need to power an expanding network of mills and factories in the mid-eighteenth century, which heavily relied on coal as a fuel source, drove coal mining to new depths and created a unique problem that would ultimately lead to breakthroughs in science, technology, engineering, and mathematics. The challenge was that deeper coal mines were prone to flooding, which would halt coal production for days and weeks on end. Miners traded their pickaxes for pails and buckets as they physically carried the water up and out of the mines (Brenni, Giatti, and Barbacci, 2010). This pressing economic problem needed an informed engineering response.

Academia had already discovered some basic principles of heat, water, and steam, and during the earlyeighteenth century engineers like Thomas Savery and Thomas Newcomen had developed and improved steam pumps that turned water into steam that then rose through pipes up and out of the flooded mines (Hulse, 1999). The steam pumps designed by Savery and Newcomen were inefficient however, losing much of their thermal energy with every stroke because the steam was heated and cooled within their master cylinders. James Watt, having recognized the power this source of rising steam could generate (Marsden, 2002), applied another principle of the conservation of energy to develop a separate condenser outside the master cylinder, thereby designing an efficient steam engine that stayed hot with every stroke.

Watt's steam engine functioned as a catalyst in increasing the research and production of thermal energy scholarship and led to the birth of thermodynamics. The need to improve the efficiency of heat engines led to a closer examination of the nature of how heat moves differently through different materials and the relationship between heat and work. As Watt designed the steam engine, he had opportunities to collaborate with Joseph Black, a scientist whose work included developing a more comprehensive understanding of latent heat (the heat required to change states of matter) and specific heat (the heat energy required to raise a substance's temperature a single degree) (Kerker, 1961). In the midst of these advances, innovations in the engineering of improved thermometers also made it possible to attain more precise measurements of temperature. Thus, a series of academic discoveries were interwoven with the technological innovation of the time to make discoveries to improve our society. No one field led the innovations, but rather innovations and knowledge from each facilitated the progress that occurred in the other STEM fields (Brenni et al., 2010; Kerker, 1961; Miller, 2008).

These examples of shared discovery and innovation from the past illustrate the complexity of preparing future innovators to function in an integrated STEM environment. The period of mutually-beneficial discoveries spurred by the need to solve a pressing mining problem demonstrates the intersectionality of innovation: an economic problem became the focus of an engineering problem, and the solutions devised to solve the engineering problem were informed by scientific understandings of the physics and principles of energy and matter. Scientific understandings and an engineering approach were used to develop technology to resolve the issue. The technological developments needed refinement as safety and efficiency became social and economic priorities. Engineering and technology benefited from the steam engine and its commercialization. Mathematicians and physicists benefited from a mathematical model for heat propagation. Scientists exchanged incomplete and competing concepts of heat transfer, which facilitated the development of more comprehensive theories of thermodynamics.

Today, there are recent widespread and long-lasting changes to our planet's surface due to the accumulation and fragmentation of plastics. The amount of plastic manufactured in the first ten years of this century alone has eclipsed the total amount of plastics produced in the entire twentieth century. Single-use plastic bottles are only one of many plastic products produced, but these lightweight, inexpensive bottles are long-lived, and their mass production and disposal in the garbage will continue to pose a significant problem for centuries. As with the mining challenge described before, the current compounding problem of plastic waste can serve as a meaningful opportunity for our next generation to exercise, bridge, and expand their ability to innovate in an integrated STEM context.

\section{LITERATURE REVIEW}

Exposing students to true integration of the STEM subjects in real-world situations is important for ensuring that our society has equipped and well-informed problem solvers it may depend on for generations to come. Informal learning environments, such as summer camps, provide excellent conditions for implementing integrated learning through STEM project-based learning (PBL) while enhancing students' social environmental awareness and responsibility (Watts, 2001). Informal STEM activities can offer students opportunities to advance their STEM understanding and knowledge (Ihrig, Lane, Mahatmya, and Assouline, 2018; Mosse and Bottrell, 2016). In the 
current study, we used a combination of educational approaches to create a rich and relevant atmosphere for STEM learning that has the potential to engage students and enhance their environmental awareness.

\section{STEM Discipline Content Knowledge}

When the National Science Foundation first began to use the term "STEM", the term simply referred to the four separate and distinct fields we know as science, technology, engineering, and/or mathematics (Sanders, 2009). However, in recent years researchers and educators have begun to use the term STEM to refer to some level of integration of the disciplines. Integrative STEM education was not intended to be a new stand-alone subject area (Sanders, 2009), but was instead intended to focus on the understanding of content from the individual disciplines and how to integrate them to solve problems. Research has shown that teaching students using a careful balance of content-specific and interdisciplinary instruction helps to advance STEM integration and enhance students' learning within each STEM discipline (English, 2016). In addition, findings have indicated that the integration of STEM concepts and practices has the promise to lead to increased conceptual learning within the disciplines (Honey, Pearson, and Schweingruber, 2014). Improvement of students' learning within STEM disciplines is critical as there is a global need to increase student proficiency in both science and mathematics. According to the most recent Programme for International Student assessment (PISA) reports, 20\% of students across the Organization for Economic Co-operation and Development (OECD) countries perform below proficiency in science, and $23.4 \%$ of students perform below proficiency in mathematics (OECD, 2016). Given the need for improved student proficiency in mathematics and science, and the demonstrated benefits of presenting students with a balanced instruction of content-specific and integrated STEM instruction, it is important to support students in building knowledge and skills both within the four STEM disciplines and across disciplines (Honey et al., 2014). In the present study, we aim to find that balance by providing in-depth STEM content knowledge within an integrated STEM PBL recycling activity. In-depth STEM content knowledge in this context refers to the specific and comprehensive instruction involving an individual STEM concept designed to emphasize content-specific knowledge related to plastics recycling. Ultimately, maintaining the conceptual depth of each STEM discipline was the goal in providing in-depth STEM content knowledge instruction within the integrated STEM PBL recycling activity.

\section{True STEM Integration}

In the Next Generation Science Standards (NGSS) and the Common Core State Standards for mathematics (CCSSM), there is a call for deeper connections among STEM subjects (National Academy of Engineering and National Research Council, 2014). Integration of STEM subjects has been shown to expose students to the connections among and across STEM concepts, supporting learning and application of concepts simultaneously rather than in isolation (Ntemngwa and Oliver, 2018). Integrated STEM instruction can be understood as interdisciplinary education that combines science, technology, engineering, and mathematics, making learning more connected and relevant for students (Stohlmann, Moore, and Roehrig, 2012). Researchers have identified a truly integrated STEM project as a project that involves collaboration toward identifying solutions to a real-world problem and that requires individuals to utilize technology to explore information; apply mathematics, engineering, and science concepts; analyze evidence; and develop conclusions (Burrows, Lockwood, Borowczak, Janak, and Barber, 2018). STEM integration can be defined as the purposeful merging of the four disciplines in order to deepen understanding by contextualizing concepts, broaden understanding through socially and culturally relevant contexts, and increase interest in STEM fields (Guzey, Harwell, and Moore, 2014). Instruction that includes STEM integration has been found to be common within college level courses; however, Becker and Park (2011) indicated that early exposure to integrated approaches may yield higher student achievement scores in STEM subjects.

STEM integrated instruction that incorporates real-world contexts and issues has been shown to increase student interest and achievement in STEM subjects, yet there is a gap in the research on how to best integrate STEM disciplines and on what factors related to the integrated instruction influenced the positive outcomes (Pearson, 2017). English (2016) found that although the integration of STEM disciplines has been advocated in the literature, studies in which researchers addressed multiple STEM disciplines are scarce, often with mixed findings, insufficient directions for STEM advancement, and varied perspectives on how discipline integration can be achieved. In addition, there is a gap in the research on what integrated STEM looks like, particularly in terms of how teachers have conceptualized and implemented integrated STEM (Srikoom, Faikhamta, and Hanuscin, 2018). Several new instructional materials, programs, and specialized schools that address one or more of the STEM subjects separately have emerged, and there have been increased calls for emphasizing connections between and among the subjects (Honey et al., 2014). It is critical for students to understand and practice meaningful integration of STEM subjects in their own learning; however, this process has often been impeded in the classroom, in which one STEM subject tends to become the primary focus of classroom activities (Burrows et al., 
2018). In the present study, we defined true integration as a process by which each STEM discipline converges in a manner that emphasizes the interconnectedness of STEM subjects while maintaining the conceptual depth of each discipline. The plastics recycling context of the current study provided students the opportunity to engage in activities that were centered around real-world problems that necessitated the true integration of STEM subjects.

\section{Social Environmental Awareness and Responsibility}

Social environmental awareness and responsibility is an important characteristic to develop in children and adults in order to improve the condition of our planet and ensure a sustainable future. This term refers to one's awareness and sense of personal accountability for helping address environmental problems in the world (Watts, 2001). Research in environmental STEM education has been limited to an investigation of the effects of one-time experiences, such as field trips. As a result, there are gaps in the literature when investigating the impact of longer experiences, which is significant because the level of engagement with STEM topics and the interaction with the learning environment have different cognitive and affective impacts (Khanaposhtani, Liu, Gottesman, Shepardson, and Pijanowski, 2018). According to the Executive Office of the President (2013), the health and longevity of our nation's environmental resources depend on the acceleration of scientific and technological innovations. Environmental and societal impacts of the $21^{\text {st }}$ century drive the global urgency to improve STEM education (Kelley and Knowles, 2016). Perhaps one of the most significant impacts of society in recent history is its considerable production of waste. "Most of the 150 million tons of plastics produced around the world every day end up in landfills, the oceans, and elsewhere" ("Scientific Advances," 2018: 36). Waste and its disposal present several significant environmental, social, and economic challenges, and waste recycling has become an important focus (Yeboah, Asante, and Opoku-Asare, 2016). The problems posed by plastic waste and the identification of viable solutions have presented an opportunity to connect informal STEM learning and social environmental awareness and responsibility. Within the last four years, researchers have begun to take advantage of this opportunity to engage students in STEM fields while targeting environmental awareness and increasing students' environmental knowledge (Burrows et al., 2018; Faria, Klima, Posen, and Azevedo, 2015; Hoang and Kato, 2016; Phamduy, Milne, Leou, and Porfiri, 2015). For example, Phamduy et al. (2015) used a robotic fish project to show the potential informal learning has to engage students and the public in STEM fields while fostering awareness of environmental issues. Plastics recycling is an urgent environmental and social issue whose solutions rely on an integrated STEM approach.

\section{STEM PBL}

STEM project-based learning (PBL) is an instructional method in which students collaborate to solve problems and apply ideas through STEM-related activities that incorporate real-world scenarios. This instructional strategy originated from authors such as Dewey (1916) and Kilpatrick (1918) and includes practices such as engaging students through using a well-defined outcome within an ill-defined task (Capraro, Capraro, and Morgan, 2013), integrating at least two of the STEM disciplines in a PBL activity, and providing student-centered instruction with authentic, real-life topics (Cook and Weaver, 2015). The Common Core State Standards (CCSS), the Next Generation Science Standards (NGSS), the National Council of Teachers of Mathematics (NCTM) Principles and Standards for School Mathematics, and the Texas Essential Knowledge and Skills (TEKS) all contain requirements that integrate STEM topics.

The intent of establishing national standards is to assess and ensure that students are prepared to actively engage with and contribute to the world both within and outside of the classroom. Use of STEM PBL has been shown to be highly effective in helping students develop $21^{\text {st }}$ century skills (Galvan and Coronado, 2014). Moreover, students have been found to be more engaged with STEM content when it is presented in the form of STEM PBL instruction that merges real-world applications and rigorous content knowledge (Craft and Capraro, 2017). Fostering social environmental awareness and responsibility and addressing environmental problems such as plastic waste are global concerns that can be used as a context to provide students with engaging learning opportunities framed around authentic, real-life topics and issues related to STEM PBL (Phamduy et al., 2015). The following research question was used to guide the present study: How does instruction designed to expand both in-depth content knowledge of specific topics in mathematics and science, and integrated STEM knowledge facilitate middle school campers' development of STEM content knowledge and their sense of social environmental awareness and responsibility while working on a recycling plastics project?

\section{METHODOLOGY}

Researchers at a Research I university designed one-week residential STEM summer camps for secondary school students. During these informal STEM camps, middle school boys and girls participated in STEM project- 


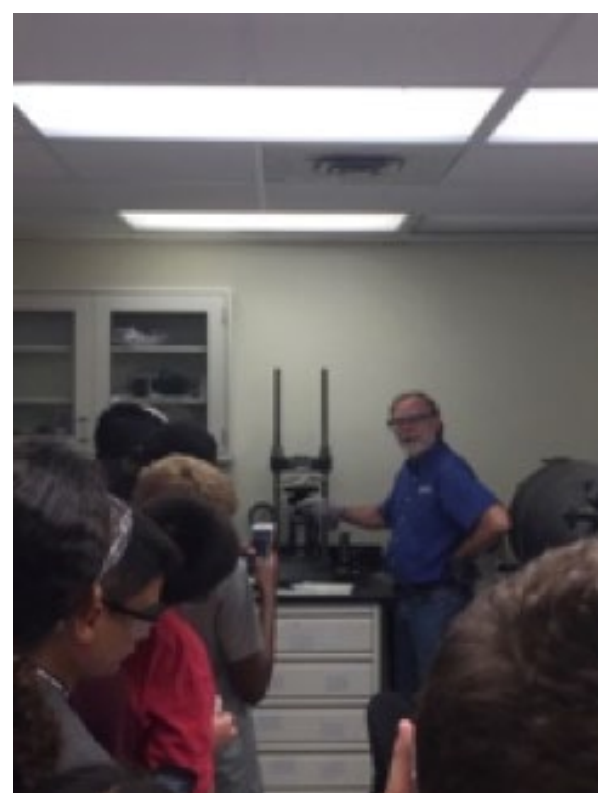

Figure 1. Campers visiting the polymer recycling lab

based, hands-on activities (PBLs), such as 3D printing and designing, aquaponics (combination of aquaculture [fish farming] and hydroponics [growing plants without soil]), app creation, bridge building, cryptography, coding, and recycling. The students engaged in PBLs for a total of 90 hours of instruction during the camps. During each of the activities, campers were required to share in discussions, create presentations, organize resources, and design products as they applied their STEM knowledge in real-life scenarios. The middle school students participated in the recycling STEM PBL activity over the course of one week. The aim of incorporating this activity in the camp was to engage the campers in the following: a) exploring the environmental problems caused to the planet's surface by the accumulation and fragmentation of plastics, b) determining how to efficiently recycle plastic bottles, c) learning how plastic is recycled, d) designing a geometrically pleasing load bearing structure with water bottles, and e) ultimately creating a unique and practical use for recycled plastics (see Appendix A for a detailed day-by-day breakdown of prior knowledge expectations, content, and learning objectives of each aspect of the camp). The campers participated in the recycling activity for 90 minutes each day of the camp under the supervision and instruction of professors and graduate students who specialize in various aspects of the STEM-related activity. The professors and graduate students who helped teach during the recycling activity were assigned to teach on specific days in which the content of the activity aligned to their area of STEM expertise (see Appendix B for a design of the instruction).

On Day 1, campers were introduced to the real-world project of solving the recycling problem and the effects of lack of recycling on our planet. In addition, they learned about the chemical building blocks that make plastics components that harm people and the environment. The following provides an overview of several key statistics and facts the campers learned. Each year, over 150,000,000 tons of plastics produced around world end up in landfills, the oceans, and elsewhere. Unfortunately, less than $9 \%$ of plastics in the world are recycled. Chemicals added to plastics are absorbed by human bodies, and plastic buried deep in landfills can leach harmful chemicals that spread into groundwater. Some of these compounds have been found to alter hormones or have other potentially negative effects on human health. Furthermore, plastic debris, laced with chemicals and often ingested by marine animals, can injure or poison wildlife. Floating plastic waste, which can survive for thousands of years in water, serves as mini transportation devices for invasive species, disrupting habitats. After being introduced to the problem and implications of plastic waste, campers were then tasked with developing an innovative product for recycling waste and were informed that the activities they would be engaging in each day of camp would build their understanding of the various sciences involved in plastics recycling. They then began their research storyboards, examining both the problem of throwing plastics into our landfills and the potential damage the various forms of waste disposal can have on the environment, including people and animals.

On Day 2, campers learned about the science behind plastics and recycling and took a tour of a laboratory on campus where plastics are recycled. During the information session, campers were also introduced to materials processing technology for thermoplastic manufacturing and recycling. Campers were familiarized with the basics of polymer science and processing/recycling information, such as what polymers can be recycled and how new and recycled polymers are molded into useful forms. During a hands-on activity, participants received polyethylene shopping bags that they cut into small, more easily melted pieces. They then visited the polymer recycling lab off campus and observed their plastic bag pieces being melted and transformed into usable polymers (see Figure 1). 


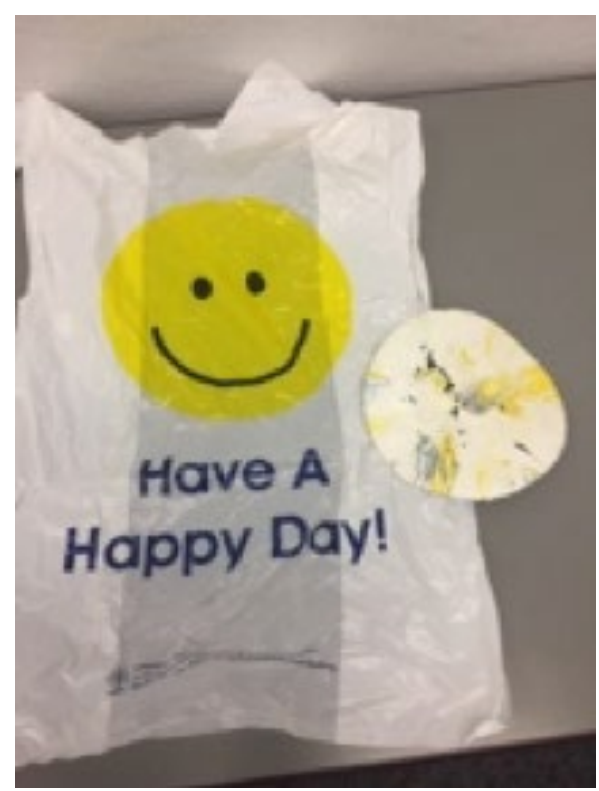

Figure 2. Plastic bag before and after

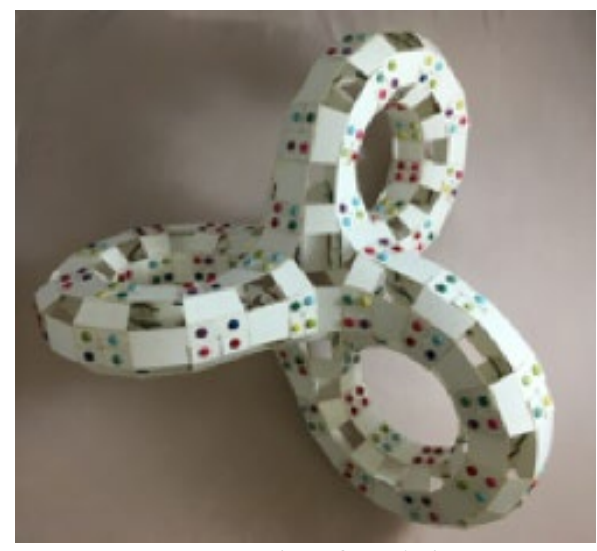

Figure 3. Example of a triple torus structure

The bags they had cut up previously were placed in a convection oven and heated to the processing temperature. The instructor demonstrated how the material was soft and flowable and could be shaped. Each charge of polymer melt was placed in a manual hydraulic press and turned into thick, flat panels. The campers could observe how the printing and colors on the bags remained and moved as the polymer flowed into its new shape. Further, campers could see the thin, flexible bags become rigid and strong sheets when consolidated into thick plates (see Figure 2).

On Day 3, campers engaged in 3D geometry and mathematical topology, providing them the background knowledge needed to design 3D shapes. Topology differs from geometry in that geometrically equivalent objects often share numerically measured quantities, such as lengths or angles, while topologically equivalent objects resemble each other in a more qualitative sense. More specifically, topology is a branch of mathematics in which two objects are considered equivalent if they can be continuously deformed into one another through such motions in space as bending, twisting, stretching, and shrinking while disallowing the tearing apart or gluing together of parts. The main idea of such topological construction comes from the fact that any surface can be decomposed using vertices. During the 3D printing component of the recycling activity, the instructor introduced both geometric and topological concepts and associated terminology. Terminology introduced during the activity included terms such as face, edges, base, congruent, intersection, solid, parallel, perpendicular, vertices, and planes. The instructor demonstrated geometrical and topological concepts. Students experimented with folding and cutting paper to apply the properties of geometric and topological shapes. To engage the students in tactile learning, the instructor had the students create various large shapes using the plastic bottles and connectors while applying geometric and topological concepts (see Figure 4). Students then used the 3-D printed bottle connectors to build 3-dimensional shapes using plastic bottles. The campers then had to apply the concepts and hands-on experience acquired to develop their final model structure. The students used this final model structure to present their unique and practical use for recycled plastics.

On Day 4, campers worked on presentations of their possible unique and practical product use for recycled plastics, which they could later construct from recycled plastics that they designed and printed in their 3-D printing 


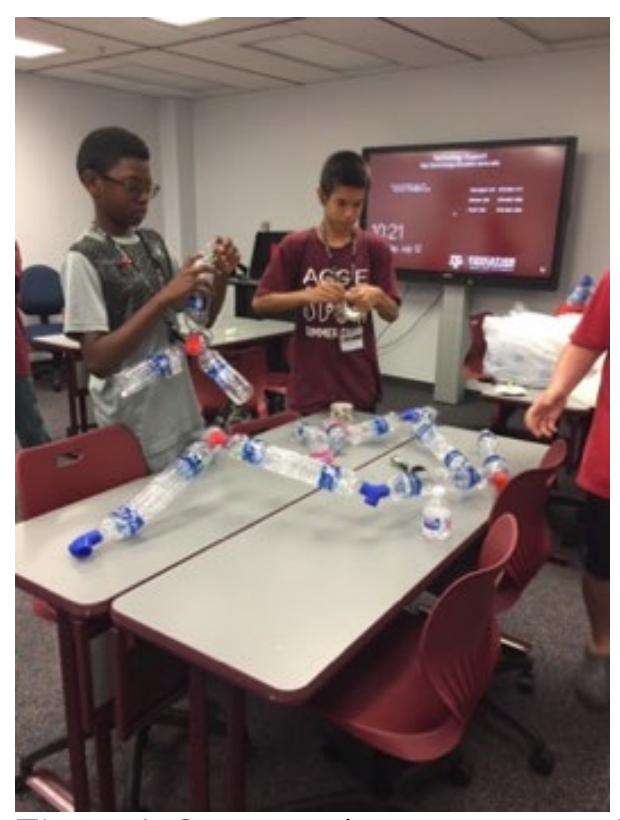

Figure 4. Campers using connectors and bottles to design a 3D shape

class. On the fifth and last day, campers presented a mock sales presentation to a group of hypothetical investors comprised of their peers and instructors. These investors could choose to fund or invest in the campers' product, which the campers could make in the future from recycled plastic filament.

A rubric was used to assess the campers' design, presentation, and marketing of their recycled product. This summative presentation rubric contained five criteria: demonstrated in-depth content knowledge in at least two STEM areas, integrated STEM knowledge, originality, engineering design process, and recycling knowledge. The "recycling knowledge" criterion measured each camper's sense of social environmental awareness and responsibility, which was assessed as both a cognitive and an action factor. As a cognitive factor, campers were assessed on their demonstrated capabilities to recognize the social and environmental issues of plastic use (Lauwrens, 2019; Sullivan, 2019; Watts, 2001). As an action factor, campers were assessed on their demonstrated capabilities to actively seek solutions to a problem or modify their own behaviors in response to the newly acquired knowledge (Gupta and Sinha, 2001). The other two criteria relevant to the current paper were "demonstrated indepth content knowledge in at least two STEM areas" and "integrated STEM knowledge." These criteria were used to determine if campers were adequate in their application of the integration of STEM disciplinary knowledge and their ability to articulate the integration of in-depth knowledge in at least two STEM subjects during the presentation of their unique product. The first of these will be discussed later in the paper.

The criterion "integrated STEM knowledge" had a rating scale of 4 along with the concrete indicators or descriptors. After engaging in the camp's informal learning activities while developing their product and preparing their presentation, we expected students to at least talk about the Science of recycling, the Technology of using the 3D printer; the Engineering design process involved in their product development, and the Mathematical geometry of measuring. To receive a 4 , the indicator required that a student needed to demonstrate how they integrated their knowledge of the STEM topics in developing their recycled product and their argument was fully developed and supported; a 3 indicated they adequately developed their recycled product using their knowledge of integrating STEM topics and their argument was adequately supported and occasionally repetitive; a 2 was given when students partially developed a limited understanding of integrating STEM topics as they described their recycled product and their presentation was repetitive; a 1 indicated a very limited and basic understanding of how they integrated the STEM topics with a minimally developed and supported recycled product and presentation.

\section{Participants}

This pilot study was conducted with middle school students during a one-week residential STEM summer camp that took place in south-central Texas during the summer of 2018. A total of 315 campers participated in the camp; however, only 9 middle school campers ( 2 females and 7 males) enrolled in the summer camp that included the plastic recycling PBL activity that was the focus of the present study. These campers were entering grades 7 through 9 during the upcoming academic year and were primarily from Texas cities, although several participants were from other states across the U.S. The ethnic demographics for all the campers $(n=315)$ were the following: White $(55 \%)$, Hispanic (23\%), Asian (7\%), Black (6\%), Indian $(2 \%)$, or N/A $(8 \%)$, indicating no specific ethnicity. 


\section{RESULTS}

The purpose of this study was to answer the following: How does instruction designed to expand both in-depth content knowledge in mathematics and science and integrated STEM knowledge facilitate middle school campers' development of STEM content knowledge and their sense of social environmental awareness and responsibility while working on a recycling plastics project? All week, campers worked on a proposal to hypothetical investors. Campers were tasked to create a proposal for a recycling product that would help to address the issue of plastic waste and pollution resulting from everyday plastic use. In order to emphasize the STEM aspects in learning, one constraint was that the campers could not make an art project. ${ }^{1}$ Campers were provided the design challenge on the first day of camp to allow them to intentionally seek STEM knowledge and to think about the practical application of that knowledge while going through content-specific activities in each of the topics described above. Additionally, campers were expected to design a product (engineering) in conjunction with the 3-D printing class (technology) they were dual enrolled in. The engineering design process was included in another class they took during the week. In our recycling class, the science of recycling and the mathematics necessary to effectively design a product from recycled plastics (social environmental awareness and responsibility) were the focus. Thus, all four STEM topics were included in the learning process.

The nine participating campers were allowed to work individually or in self-selected groups to produce a final recycling product and presentation. Two of the campers worked individually on their own projects and seven campers chose to work in two separate groups. This process resulted in four total presentations, three of which were interactive PowerPoint presentations and one of which was a 24 by 36-inch presentation storyboard. Each of the campers appeared enthusiastic about the project. They started their presentations by articulating the environmental damages that non-recycled plastics cause. Their voices and body language suggested an intense level of involvement in the project. However, the actual design of the projects they created did not demonstrate an indepth level of STEM knowledge reflective of the activities they were engaged in during the camp.

"The research team independently rated the summative presentations on a 5-point scale as to whether the, "student demonstrated in-depth content knowledge in at least two STEM areas." To achieve a score of "5," students would have had to demonstrate an in-depth level of knowledge in two or more STEM disciplines. This required evidence during a student's presentation that they engaged with and understood the complexities of the subjects they studied during camp. An example of this would be a discussion of the chemical structure of common plastics (science) and how the student utilized the engineering design process to make design decisions in the presence of constraints (engineering) for their unique product based on this knowledge. Unfortunately, none of the students demonstrated an in-depth level of content knowledge in two or more STEM disciplines during their presentations. Seven of the students received a " 2 " on this indicator, while two received a "1" on this indicator. Scores below a " 3 " indicated that students did not incorporate the concepts and terminology taught during the activities into their culminating presentation. Interrater reliability was not calculated due to the small sample size.

In one project, called Nasco Plastic Reduction, the participants proposed a rudimentary business idea with three steps: 1) investing in existing plastic reduction activities, such as individuals, programs, and volunteers; 2) investing in toys and arts that are made through the use of plastic recycling; and 3) setting up a network for interested helpers. At the beginning of step 1, the camper listed "setting up trust", although it should have been an independent step. The proposal did not involve the design of a physical product but instead the design of a marketing strategy, which indicated the campers realized the connection between STEM-based ideas and the outreach to the society through economic means.

In a second project, entitled Recycled Garden, the camper proposed designing gardening devices that use common plastic objects such as pots to hold plants. The camper downloaded images from the internet as a proof of the concept but did not have time to come up with an original design (see Figure 5). There was no detailed explanation about materials needed, water saturation, temperature, or irrigation. The participant attempted to emphasize the fun factor of the project, which may be how he or she thought the project could be successful (see Figure 6). Although the participant did not articulate in detail what aspects of this product and its creation are fun, the fun factor appears to be critical in young participants' value system. It is worth an in-depth investigation in our future research.

The project AquaPure stood out as it was the most detailed example among all of the proposals in terms of the participants examining and designing the mechanism of a device (see Figure 7). Two participants collaborated on this project. They proposed a water filtration system that used plastic water bottles as a container of filtration agents including sand, rocks, and cotton. The campers used the plastic bottles upside down and utilized the narrowing area of the original bottle opening as a funnel. One may argue that the campers' selection of images of layered filtration agents and their use of the upside down positioned plastic bottle demonstrated their intuitive

${ }^{1}$ Although STEM and art intersect, the complexity of art can easily direct the participating campers to focus on expressing feelings instead of identifying problems and finding solutions. 


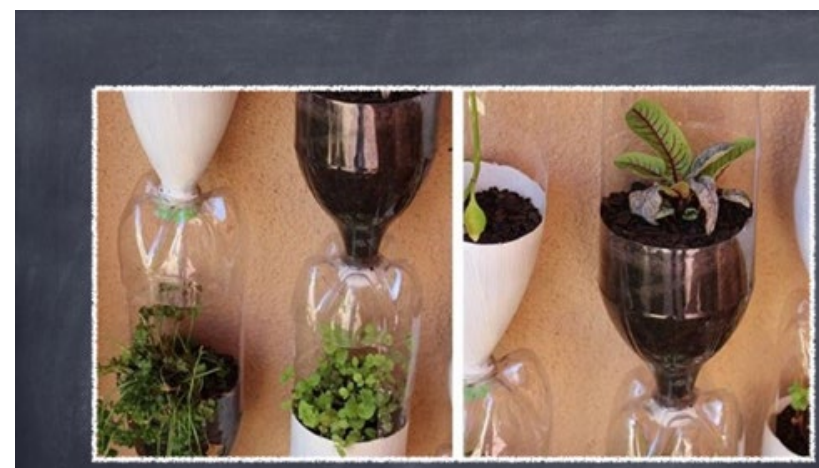

Using everyday objects like plastic bottles can be reused instead of being trashed.

Figure 5. Campers recycled garden design concept presentation

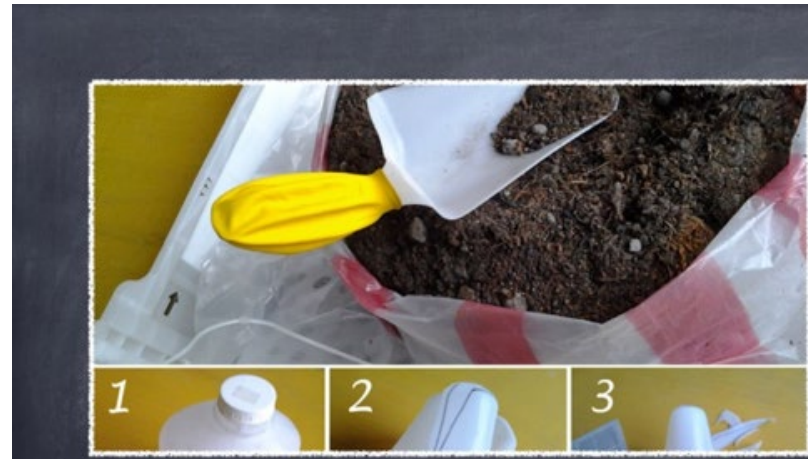

\section{Reusing objects for your garden is easy and fun!}

Figure 6. The fun factor of the recycled garden design concept presentation

\section{THE IDEA}
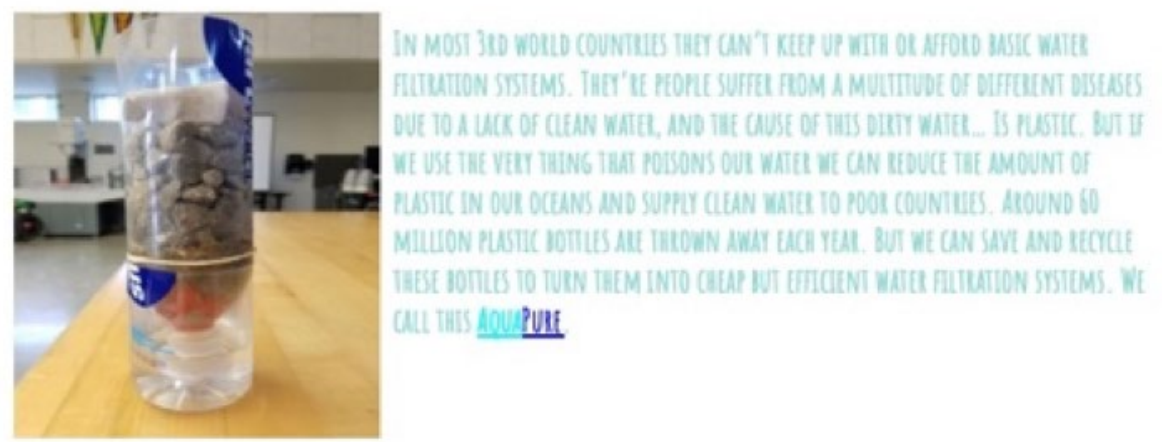

Figure 7. AquaPure project presentation

grasp of the engineering of filtration. However, the campers did not truly engineer their own filtration system. Further, this project revealed the campers' lack of knowledge about plastic bottles' toxicity. Chemicals in plastics can be unstable under the sunlight and after a period of use. Reusing these bottles to filtrate drinking water may pose a question of water and food safety.

The final project, a Museum Information Storyboard, was created as a museum display to inform visitors about the recycling process, including the ramifications of the damage lack of recycling causes. The storyboard incorporated an introduction of the rationale of plastic recycling, which demonstrated the camper's strong sense of social environmental awareness and responsibility. The camper also incorporated a copy of an image found online from 


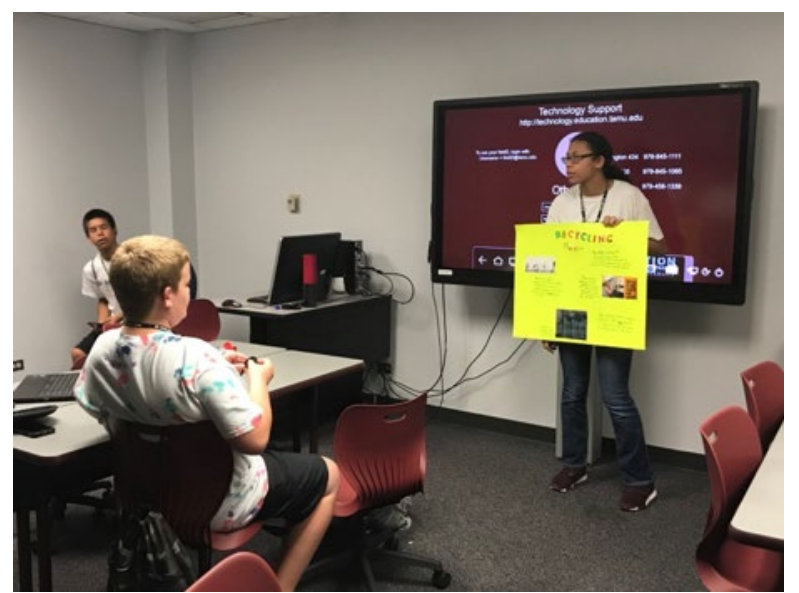

Figure 8. Camper presenting museum information storyboard

a plastic recycling DIY website (www.preciousplastic.com) on his storyboard. The image presents an outline of how a recycling system can be fabricated with off-the-shelf components. In fact, this recycling system has been used by Dave Hakkens, the founder of Precious Plastic in collaboration with people who live in under-developed areas. The camper's storyboard also included a design of how museum visitors could bring their plastic bottles to the museum, place the bottles in a machine, and get tokens made from the plastic bottles to use for access to museum activities in exchange for recycling their plastics. The design idea was promising in terms of engaging museum visitors although its representation in the camper's presentation was limited (see Figure 8); the camper provided a single image from the internet and no more than one sentence of description regarding the design of the machine.

\section{DISCUSSION}

The results observed in the participants' final presentations indicated mixed learning outcomes. While some of the group projects seemed to indicate that the students might have marginally increased their content knowledge, most of the projects lacked a clear application of in-depth STEM content knowledge. For instance, the camper who created the museum information storyboard provided an outline of how off-the-shelf components could be used to fabricate a recycling system. We could perhaps assume that the camper required some degree of knowledge about the process detailed in the outline in order to present the outline to his peers; however, the camper had found the outline on the internet and merely made a copy to include on his museum storyboard. Therefore, when examining this particular camper's presentation, it is difficult to determine the extent of in-depth STEM knowledge the camper acquired.

The nature of the results from the other group projects posed a similar problem. For instance, the Nasco Plastics Reduction group did not design a product, the camper who created the Recycled Garden product did not provide detailed explanation about materials needed, water saturation, temperature, or irrigation, and the AquaPure group lacked knowledge about plastic bottles' toxicity. Several factors may have attributed to the lack of demonstrated in-depth and integrated STEM knowledge in these projects. Time constraints and the nature of the project guidelines could have significantly influenced the campers' final products and presentations. Further development of the guidelines for the final presentations and products could better ensure that students apply the knowledge and concepts they were taught during the recycling class when designing their final products and presentations. In addition, engaging students in the plastics recycling project for a longer period may provide them with a more sufficient timeframe in which to acquire and solidify their in-depth and integrated STEM knowledge. Furthermore, increasing the duration of the plastics recycling project would provide students with additional time to design their final product and presentation as well. Further research is required to determine clearly how engaging in a plastic recycling activity influences both students' in-depth content knowledge and integrative STEM knowledge.

Although campers did not demonstrate clear improvement in their integrated and in-depth STEM content knowledge, they did display a sense of social environmental awareness and responsibility while presenting their product or strategy for reducing plastic waste. In fact, most of the student groups introduced their projects in the context of plastic pollution and presented their STEM projects as a solution to the recycling problem. Most students also discussed their future intended behavior, including a willingness to continue and/or modify their current practices in order to reduce plastic pollution. Through these actions, students clearly demonstration their social and environmental awareness. This awareness was most evident in the Nasco Plastic Reduction groups' marketing strategy, which demonstrated that the campers understood the connection between STEM-based ideas 
and outreach to the society. All participants stressed and understood the importance of recycling in mitigating the amount of waste produced and in ensuring a sustainable future.

When reflecting on the conclusions of the present study it is important to recognize the unique opportunity informal learning offers educators and administrators. At the time of this publication, K-12 public school systems have no uniformly or commonly recognized model of STEM integration (e.g., Bybee, 2013; Ring-Whalen, Dare, Roehrig, Titu, and Crotty, 2018). Informal settings are able to function in tandem with or outside the structure of high-stakes assessments and can therefore be a suitable test bed for STEM integration strategies prior to their implementation in a highly structured formal learning context. The present study can be used in such a way.

Through this pilot program, the researchers identified effective instructional components within the intervention as well as several limitations and challenges, all of which will be used to guide and refine the recycling plastics intervention in future studies. One particular challenge highlighted in the present study is the difficulty in isolating and emphasizing engineering principles and design within the time frame and grade level of the campers. Engineering is the design, or creation, of objects and systems that do not occur naturally to enhance the current state of the world. However, this does not happen by blind trial and error. Design decisions are to be thoughtfully made using engineering principles and tested using multiple models, from mathematical to physical prototypes, so that the end product responds in a predictable and desirable fashion under a range of conditions. Engineering principles include the ideas, rules, or concepts that must be considered during the design process. These are problem and context specific, so no single list applies. Therefore, an engineer must learn to develop models that capture the critical behaviors needed to make design decisions and predict system response. Guiding students through this process is critical to help them understand the various principles of engineering and engineering design. Although the basic components of an engineering design cycle were present in the campers' learning processes in the recycling activity, the time in which to teach students about this information was limited, as was the time available for students to apply the engineering principles in designing their final recycling product.

Therefore, we aim to evaluate the strengths and limitations of the recycling activity to determine how best to modify the activity and thereby optimize students' learning experience. Our current project was limited in results due to the length of the one-week camp even though we were able to work cooperatively with the engineering design activity and the $3 \mathrm{D}$ printing instructors. The informal setting provides some affordances that might not be present in a formal setting, though there are also serious constraints. The informal setting removes stress on students and faculty to master specific learning objectives within a certain timeframe and it provides the opportunity for learning in a more relaxed environment. However, the lack of pressure may also contribute to a lack of motivation to fully commit to the learning tasks. In a formal school setting, teachers of science, technology, engineering, and mathematics can work cooperatively to plan and enact the project together over a two-week period to allow the interdisciplinary nature of the project to be fully implemented. This would minimize the stress to compress time for mastering specific objectives while providing some authentic learning experiences. However, being situated within a formal setting, students who are extrinsically motivated would be more sufficiently focused on ensuring they are learning the content and working conscientiously to complete the task.

A key component for our future research will be how to introduce the rigor of system modeling and design choices into the process without stifling student creativity and enthusiasm. Every system has key behaviors; for example, a long and slender beam is governed by how it bends, and a column is governed by axial compressions. However, a column also has bending, and a beam has axial compressions. They both may have shear (cutting forces) and torsion (twisting forces). A key part of the engineer design process is identifying what those key behaviors are in order to continue into the process of how to build a model that captures them and how to analyze and design. The identification of the key behaviors for the campers' system must be part of that process. Enhancing the campers' understanding of these key components of the engineering design cycle will be of critical importance in the continuation of this research.

Nonetheless, there are a number of insights that can be gleaned from the present study. It is inherently challenging to formally assess students who are voluntarily participating in an informal STEM Camp. In fact, formal assessments may run counter to a student's agenda for participating and may mitigate motivation at some level. Even performance-based assessments are complicated by the fact that students may leave out crucial elements of their STEM learning process when presenting their ideas, making students' extent of in-depth STEM knowledge difficult to determine. This would include discussion of and rationale for the planning and redesign phases and drawn designs and how these may have evolved and changed. Future studies should investigate how to balance assessments and motivation in STEM learning. Additionally, participation in the informal STEM camp is limited to a single week; measuring long-term learning benefits may also be a limitation of this present study.

Learning to discuss and present one's own learning process and being able to explain how it occurs are important skills and part of the progression of learning to be meta-cognitive and to reflect meta-cognitively. Finally, teachers should build the skills necessary to teach students to present their learning, while schools should invest in 
helping teachers become adept at PBL instructional methods and set aside funding to support student attendance of informal summer programs, where leaning can be more focused on big ideas.

\section{REFERENCES}

Becker, K. and Park, K. (2011). Effects of integrative approaches among science, technology, engineering, and mathematics (STEM) subjects on students' learning: A preliminary meta-analysis. Journal of STEM Education: Innovations \& Research, 12, 23-37.

Brenni, P., Giatti, A. and Barbacci, S. (2010). Case study 2: Steam, work, energy. Available at: http://hipstwiki.wikifoundry.com/page/Case+Study+2

Burrows, A., Lockwood, M., Borowczak, M., Janak, E. and Barber, B. (2018). Integrated STEM: Focus on informal education and community collaboration through engineering. Education Sciences, 8, 1-15. https://doi.org/10.3390/edusci8010004

Bybee, R. W. (2013). The case for STEM education: Challenges and opportunities. Arlington, VA: NSTA Press.

Capraro, R. M., Capraro, M. M. and Morgan, J. (Eds.). (2013). STEM Project-based learning: An integrated science, technology, engineering, and mathematics (STEM) approach (2nd Ed.). Rotterdam, The Netherlands: Sense.

Chandra, P. and Dong, A. (2015). Knowledge accumulation and the value of inventions. Proceedings of the 2015 Portland International Conference on Management of Engineering and Technology (PICMET), 2187-2194. https://doi.org/10.1109/PICMET.2015.7273056

Cook, N. D. and Weaver, G. G. (2015). Teachers' implementation of project-based learning: Lessons from the research goes to school programs. Electronic Journal of Science Education, 19(6), 1-45.

Craft, A. and Capraro, R. M. (2017). Science, technology, engineering, and mathematics project-based learning: Merging rigor and relevance to increase student engagement. Electronic International Journal of Education, Arts, and Science, 3, 140-158.

Dewey, J. (1916). Democracy and education. New York, NY: Macmillan.

English, L. D. (2016). STEM education K-12: Perspectives on integration. International Journal of STEM Education, 3, 1-8. https://doi.org/10.1186/s40594-016-0036-1

Executive Office of the President, National Science and Technology Council, Committee on STEM Education. (2013). Federal Science, Technology, Engineering, and Mathematics (STEM) Education: 5-Year Strategic Plan. Available at: http:// ezproxy.library.tamu.edu/login?url=http:// search.ebscohost.com/login.aspx?direct=true\&db=eric\&A $\mathrm{N}=\mathrm{ED} 570924 \&$ site $=$ eds-live

Faria, F., Klima, K., Posen, I. D. and Azevedo, I. M. L. (2015). A new approach of science, technology, engineering, and mathematics outreach in climate change, energy, and environmental decision making. Sustainability: The Journal of Record, 8, 261-271. https://doi.org/10.1089/SUS.2015.29023

Galvan, M. E. and Coronado, J. M. (2014). Problem-based and project-based learning: Promoting differentiated instruction. Nation Teacher Education Journal, 7(4), 39-42.

Gupta, A. K. and Sinha, R. (2001). Environmental conservation: Ethical concerns. In N. J. Smelser \& P.B. Baltes (Eds.), International encyclopedia of the social \& behavioral sciences (pp. 4602-4607). London, UK: Elsevier. https://doi.org/10.1016/B0-08-043076-7/04178-4

Guzey, S. S., Harwell, M. and Moore, T. (2014). Development of an instrument to assess attitudes toward science, technology, engineering, and mathematics (STEM). School Science and Mathematics, 114, 271-279. https://doi.org/10.1111/ssm.12077

Hoang, T. T. P. and Kato, T. (2016). Measuring the effect of environmental education for sustainable development at elementary schools: A case study in Da Nang city, Vietnam. Sustainable Environment Research, 26, 274-286. https://doi.org/10.1016/j.serj.2016.08.005

Honey, M., Pearson, G. and Schweingruber, H. A. (2014). STEM integration in K-12 education: Status, prospects, and an agenda for research. Washington, DC: The National Academies Press.

Hulse, D. K. (1999). The early development of the steam engine. Leamington Spa, UK: TEE Publishing.

Ihrig, L. M., Lane, E., Mahatmya, D. and Assouline, S. G. (2018). STEM excellence and leadership program: Increasing the level of STEM challenge and engagement for high-achieving students in economically disadvantaged rural communities. Journal for the Education of the Gifted, 41, 24-42. https://doi.org/10.1177/ 0162353217745158

Kelley, T. R. and Knowles, J. G. (2016). A conceptual framework for integrated STEM education. International Journal of STEM Education, 3, 1-11. https:// doi.org/10.1186/s40594-016-0046-z

Kerker, M. (1961). Science and the steam engine. Technology and Culture, 2, 381-390. https://doi.org/10.2307/ 3100893 
Khanaposhtani, M. G., Liu, C. J., Gottesman, B. L., Shepardson, D. and Pijanowski, B. (2018). Evidence that an informal environmental summer camp can contribute to the construction of the conceptual understanding and situational interest of STEM in middle-school youth. International Journal of Science Education, Part B: Communication and Public Engagement, 8, 227-249. https://doi.org/10.1080/21548455.2018.1451665

Kilpatrick, W. H. (1918). The project method. Teachers College Record, 19, 319-335.

Lauwrens, M. (2019). How to cultivate environmental awareness in schools. Available at: https://www.gviusa.com/blog/how-to-cultivate-environmental-awareness-in-schools/

Marsden, B. (2002). Watt's perfect engine. New York, NY: Columbia University Press.

Miller, D. P. (2008). Seeing the chemical steam through the historical fog: Watt's steam engine as chemistry. Annals of Science, 65, 47-72. https://doi.org/10.1080/00033790701503127

Mosse, J. and Bottrell, C. (2016). The importance of place in evaluation of STEM partnerships between Universities and Schools in rural, remote and regional Australia. Australasian Journal of University-Community Engagement, 10(2), $19-43$.

National Academy of Engineering and National Research Council. (2014). STEM integration in K-12 education: Status, prospects, and an agenda for research. Washington, DC: The National Academies Press.

Ntemngwa, C. and Oliver, J. S. (2018). The implementation of integrated science, technology, engineering, and mathematics (STEM) instruction using robotics in the middle school science classroom. International Journal of Education in Mathematics, Science, and Technology, 6, 12-40. https://doi.org/10.18404/ijemst.380617

OECD (2016). PIS A 2015 results (Volume I): Excellence and equity in education. Paris, France: OECD Publishing.

Pearson, G. (2017). National academies piece on integrated STEM. The Journal of Educational Research, 110, 224-226. https://doi.org/10.1080/00220671.2017.1289781

Phamduy, P., Milne, C., Leou, M. and Porfiri, M. (2015). Interactive robotic fish: A tool for informal science learning and environmental awareness. IEEE Robotics \& Automation Magazine, 22(4), 90-95. https://doi.org/10.1109/MRA.2015.2443991

Ring-Whalen, E., Dare, E., Roehrig, G., Titu, P. and Crotty, E. (2018). From conception to curricula: The role of science, technology, engineering, and mathematics in integrated STEM units. International Journal of Education in Mathematics, Science, and Technology, 6, 343-362. https://doi.org/10.18404/ijemst.440338

Sanders, M. (2009). STEM, STEM education, STEMmania. Technology Teacher, 68(4), 20-26.

Scientific advances can make it easier to recycle plastics. (2018, March). DEMM: Engineering \& Manufacturing, p. 36.

Srikoom, W., Faikhamta, C. and Hanuscin, D. L. (2018). Dimensions of effective STEM integrated teaching practice. K-12 STEM Education, 4, 313-330.

Stohlmann, M., Moore, T. J. and Roehrig, G. H. (2012). Considerations for teaching integrated STEM education. Journal of Pre-College Engineering Education Research, 2(1), 28-34. https://doi.org/10.5703/1288284314653

Sullivan, N. (2019). Environmental awareness: Definition, bistory \& importance video. Available at: https://study.com/academy/lesson/environmental-awareness-definition-history-importance.html

Watts, D. G. (2001). Environmental studies. New York, NY: Routeledge.

Yeboah, R., Asante, E. A. and Opoku-Asare, N. (2016). Teaching interactive art lessons with recycled waste materials as instructional resources. Journal of Education and Practice, 7(14), 38-59. 


\section{APPENDIX A}

\begin{tabular}{|c|c|c|c|c|c|}
\hline & \multirow{2}{*}{$\begin{array}{l}\text { Anticipated } \\
\text { Prior Knowledge }\end{array}$} & \multirow{2}{*}{$\begin{array}{l}\text { Disciplinary } \\
\text { Experience/ Context }\end{array}$} & \multicolumn{2}{|c|}{ Targeted Learning Outcomes } & \multirow{2}{*}{$\begin{array}{l}\text { Evidence of Learning } \\
\text { in Product }\end{array}$} \\
\hline & & & Cognitive Outcomes & Affective Outcomes & \\
\hline$\overline{\text { Day } 1}$ & $\begin{array}{l}\text { Recognize everyday } \\
\text { uses of plastics. } \\
\text { Recognize that certain } \\
\text { types of paper, plastic, } \\
\text { metal, and glass are } \\
\text { recyclable. }\end{array}$ & $\begin{array}{l}\text { Overview of the } \\
\text { plastics problem. } \\
\text { Discuss the chemistry } \\
\text { of plastic and dangers } \\
\text { of plastic waste. } \\
\text { Discuss the } \\
\text { Engineering Design } \\
\text { Process. }\end{array}$ & $\begin{array}{l}\text { Describe the main } \\
\text { points of the plastics } \\
\text { problem, including the } \\
\text { nature of plastic, the } \\
\text { role of humans, and the } \\
\text { importance of } \\
\text { recycling. } \\
\text { Identify the steps of the } \\
\text { Engineering Design } \\
\text { Process. }\end{array}$ & $\begin{array}{l}\text { Recognize and value } \\
\text { the urgency and } \\
\text { relevance of the plastics } \\
\text { problem. } \\
\text { Identify one's role and } \\
\text { responsibility to be a } \\
\text { part of the solution to } \\
\text { the plastics problem. }\end{array}$ & $\begin{array}{l}\text { As students begin } \\
\text { brainstorming } \\
\text { solutions, there should } \\
\text { be evidence of the } \\
\text { impact of plastic waste } \\
\text { on landfills and living } \\
\text { organisms in their } \\
\text { research storyboard. }\end{array}$ \\
\hline$\overline{\text { Day } 2}$ & $\begin{array}{l}\text { Describe, measure, and } \\
\text { test common physical } \\
\text { and chemical properties } \\
\text { of matter. } \\
\text { Although the word } \\
\text { polymer may not be } \\
\text { familiar, students } \\
\text { should be able to } \\
\text { recognize shared traits } \\
\text { of objects made with } \\
\text { polymers. }\end{array}$ & $\begin{array}{l}\text { Explore the field of } \\
\text { polymer science and its } \\
\text { relation to plastics and } \\
\text { recycling. } \\
\text { Explore polymers and } \\
\text { thermoplastics during a } \\
\text { plastics recycling lab } \\
\text { tour. }\end{array}$ & $\begin{array}{l}\text { Observe and describe } \\
\text { which physical } \\
\text { properties changed and } \\
\text { which remained } \\
\text { unchanged during the } \\
\text { plastic recycling } \\
\text { process. } \\
\text { Describe what a } \\
\text { polymer is and identify } \\
\text { examples of common } \\
\text { polymers. }\end{array}$ & $\begin{array}{l}\text { Recognize and value } \\
\text { the time, energy, and } \\
\text { resources it takes to } \\
\text { transform plastic waste } \\
\text { into a new product. }\end{array}$ & $\begin{array}{l}\text { As students continue to } \\
\text { develop and refine their } \\
\text { proposed solution to } \\
\text { the plastics problem, } \\
\text { there should be } \\
\text { evidence of } \\
\text { opportunities to } \\
\text { repurpose polymers } \\
\text { from plastic bags into } \\
\text { new plastic molds in } \\
\text { their research } \\
\text { storyboard. }\end{array}$ \\
\hline Day 3 & $\begin{array}{l}\text { Name and describe } \\
\text { features of common } \\
\text { 3D shapes. } \\
\text { Be familiar with } \\
\text { filament-based 3D } \\
\text { printing tools. }\end{array}$ & $\begin{array}{l}\text { Explore geometry \& } \\
\text { topology through } \\
\text { hands-on model } \\
\text { building. } \\
\text { Fold and transform } \\
\text { paper and construct } \\
\text { geometric shapes with } \\
\text { plastic bottles and } \\
\text { connectors. }\end{array}$ & $\begin{array}{l}\text { Make connections } \\
\text { between recycled } \\
\text { plastic polymers and } \\
\text { the filament used in 3D } \\
\text { printing. } \\
\text { Build and describe 3D } \\
\text { shapes by their shared } \\
\text { features. }\end{array}$ & $\begin{array}{l}\text { Recognize and value } \\
\text { the complexity of } \\
\text { topology as it relates to } \\
\text { product design. } \\
\text { Identify alternative uses } \\
\text { for repurposing } \\
\text { materials. }\end{array}$ & $\begin{array}{l}\text { As students continue to } \\
\text { refine their proposed } \\
\text { solution, their design } \\
\text { should include } \\
\text { evidence of the use of } \\
\text { more complex shapes } \\
\text { and topologies to } \\
\text { mirror their } \\
\text { experiences with } \\
\text { compounding } \\
\text { structures. }\end{array}$ \\
\hline Day 4 & $\begin{array}{l}\text { Be familiar with the } \\
\text { Engineering Design } \\
\text { Process. } \\
\text { Be familiar with making } \\
\text { a persuasive argument } \\
\text { to a target audience. }\end{array}$ & $\begin{array}{l}\text { Use the Engineering } \\
\text { Design Process to } \\
\text { develop a prototype } \\
\text { solution to the plastics } \\
\text { problem. } \\
\text { Create a proposal } \\
\text { presentation for a } \\
\text { mock investor panel. }\end{array}$ & $\begin{array}{l}\text { Apply the Engineering } \\
\text { Design Process to } \\
\text { develop a solution. } \\
\text { Work collaboratively } \\
\text { with peers. } \\
\text { Use scientifically and } \\
\text { mathematically correct } \\
\text { terminology. }\end{array}$ & $\begin{array}{l}\text { Recognize and value } \\
\text { the challenge of } \\
\text { integrating ideas from } \\
\text { different disciplines } \\
\text { (STEM) into } \\
\text { comprehensive } \\
\text { solutions to real- world } \\
\text { problems. }\end{array}$ & $\begin{array}{l}\text { As students finalize } \\
\text { their proposed } \\
\text { solution, there should } \\
\text { be evidence of specific } \\
\text { science, technology, } \\
\text { engineering, or } \\
\text { mathematics concepts } \\
\text { and their layered } \\
\text { application in their } \\
\text { research storyboard. }\end{array}$ \\
\hline Day 5 & $\begin{array}{l}\text { Know the protocols } \\
\text { associated with } \\
\text { presenting to an } \\
\text { audience. }\end{array}$ & $\begin{array}{l}\text { Present proposed } \\
\text { solution to a panel of } \\
\text { mock investors. } \\
\text { Provide constructive } \\
\text { feedback to peers. }\end{array}$ & $\begin{array}{l}\text { Demonstrate specific } \\
\text { disciplinary knowledge } \\
\text { in at least two areas of } \\
\text { STEM. } \\
\text { Demonstrate ability to } \\
\text { integrate STEM ideas } \\
\text { into a novel solution. }\end{array}$ & $\begin{array}{l}\text { Demonstrate social } \\
\text { environmental } \\
\text { awareness and } \\
\text { responsibility. } \\
\text { Demonstrate originality } \\
\text { in proposed plastics } \\
\text { recycling solution. }\end{array}$ & $\begin{array}{l}\text { Students should } \\
\text { demonstrate in-depth } \\
\text { content knowledge in } \\
\text { at least two STEM } \\
\text { areas, integrated STEM } \\
\text { knowledge, originality, } \\
\text { use of the engineering } \\
\text { design process, and } \\
\text { application of their } \\
\text { disposition towards } \\
\text { recycling. }\end{array}$ \\
\hline
\end{tabular}




\section{APPENDIX B}

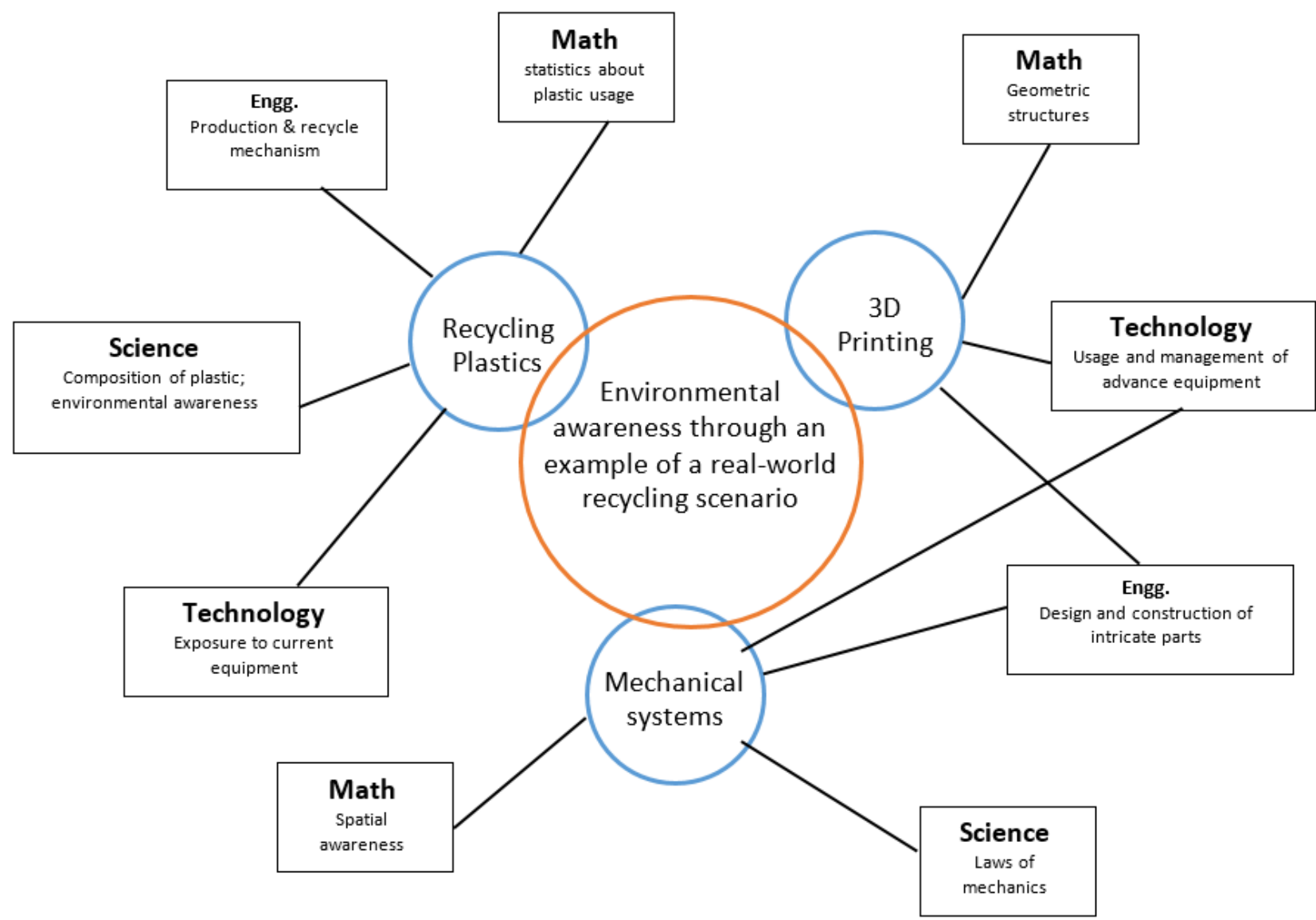

